\title{
O badaniach biograficznych krytycznie
}

\begin{abstract}
Abstrakt
W naukach społecznych i humanistycznych widzimy różnorodność podejść do badań biograficznych. Powstaje więc pytanie, które z tych podejść są właściwe, a które nie? Które warto stosować i dlaczego? Artykuł ten podejmuje zagadnienie badań biograficznych z punktu widzenia krytycznego, szczególnie w czasie, kiedy różnorodność podejść, koncepcji i perspektyw może sprawiać trudności nowicjuszom w stosowaniu tej metody.

Wieloletnie posługiwanie się metodą biograficzną pozwala mi spojrzeć na własną działalność badawczą krytycznie i zastanawiać się, jak stosowanie metody abdukcyjnej do generowania teorii dotyczącej konstruowania i rekonstruowania tożsamości nietradycyjnych studentów w szkolnictwie wyższym w Szwecji jest możliwe i jakie są tego konsekwencje.

Artykuł ten stara się pokazać początki metody biograficznej, usytuować ją w kontekście nauk społecznych, zastanowić się nad różnymi podejściami, pułapkami oraz zaletami i wadami tej metody. Równocześnie przedstawia problemy w stosowaniu metody wywiadu biograficznego, doboru próby, zagadnień etycznych oraz analizy danych, jak i konceptualizacji danych oraz tworzenia typologii na przykładzie własnych badań.
\end{abstract}

Słowa kluczowe: metoda biograficzna, abdukcja, analiza, typologia studentów.

\section{Critical Approach to Biographical Research}

\begin{abstract}
In social sciences and humanities, a variety of approaches to biographical research are used. The question then arises what is appropriate and what is not? Which approach is worth using and why? This article looks at biographical research from the critical point of view, especially at a time when the diversity of approaches, concepts, and perspectives can make it difficult for novices to use this method.

Having long experience in applying the biographical method allows me to look critically at my own research and think about using the abductive method to generate
\end{abstract}

\footnotetext{
* Uniwersytet Sztokholmski, Instytut Pedagogiki.
} 
a theory on identity formation and transformation by non-traditional students in higher education in Sweden. How is this possible and what are the consequences?

This article tries to show the beginnings of the biographical method in the context of social sciences and reflects on the different approaches, pitfalls as well as advantages and disadvantages. It presents problems in applying biographical interview, sampling, ethical issues, data analysis and conceptualization as well as creation of typology on the example of my own research.

Keywords: biographical method, abduction, analysis, students' typology.

\section{Moja droga do badań biograficznych}

Kiedy po kilku latach pobytu w Szwecji zaczęłam intelektualnie i emocjonalnie zmagać się z problemem mojej własnej emigracji, wpadła mi w ręce biografia Floriana Znanieckiego i ku memu zdumieniu odkryłam, że Znaniecki borykał się z podobnymi problemami w USA w latach 20 -tych i potem 40-tych XX w. (Dulczewski 1984; Szacki 1986). Szczególnie ciekawe było to, że Znaniecki jako badacz obracał się w środowiskach akademickich, tak jak i ja to robiłam w ciągu całego mojego życia. Poznałam również środowiska akademickie w Ameryce Północnej (USA i Kanadzie). Po dziewięciu miesiącach od przyjazdu do Szwecji rozpoczęłam badania na Uniwersytecie w Uppsalii, ale te nie dotyczyły jeszcze badań biograficznych, lecz porównawczych obejmujących duży materiał z USA, NRF, Jugosławii i Polski. Badałam wtedy dostęp robotników do kształcenia na poziomie wyższym (Bron-Wojciechowska 1989).

Zafascynowana biografią Znanieckiego zaczęłam czytać jego dzieło pisane wspólnie z Isakiem Thomasem o Chłopie polskim w Europie i Ameryce w oryginale, czyli po angielsku (polskie tłumaczenie z 1976 r. dostałam dopiero później). 0 metodzie biograficznej i konkursach na pamiętniki wiedziałam jeszcze z moich studiów i pracy na Uniwersytecie Warszawskim. Stąd wiodła już prosta droga do zastosowania metody biograficznej we własnych badaniach.

Dwa jeszcze inne czynniki wpłynęły na podjęcie badań biograficznych. Pierwszy to moje zainteresowanie psychologią człowieka dorosłego. Wyjeżdżając z Polski na stypendium do SUNY w Stony Brook, jechałam m.in. z zadaniem znalezienia publikacji i badań dotyczących rozwoju człowieka dorosłego. W Polsce takie badania wtedy nie istniały, jedyną publikacją była niewielka książeczka Włodzimierza Szewczuka Psychologia człowieka dorosłego (1959). W USA zgromadziłam duży materiał z psychologii rozwojowej i psychologii społecznej dotyczącej tej problematyki.

Drugim czynnikiem była moja praca dydaktyczna ze studentami na Uniwersytecie w Linköping. Byli to dorośli studenci, przygotowujący się do pracy nauczycielskiej na uniwersytetach ludowych. Nie bardzo byli chętni do czytania literatury przedmiotu i wtedy to przyszedł mi do głowy pomysł, żeby zastosować metodę 
biograficzną w nauczaniu. Lata pracy z tą metodą, jak również projekt badawczy, jaki prowadziłam w latach 1986-1990 na temat Zmian życiowych wśród dorosłych jako czynnika uczenia się: Studium przypadku życia emigrantów w Szwecji, przyczynił się do powstania koncepcji floating - zawieszenia, którą później rozwinęłam i weryfikowałam na innych materiałach badawczych. Nota bene badania moje nad emigrantami dotyczyły Polaków (Bron 1999, 2000, 2009).

Doświadczenia z metodą biograficzną, uczenie i kierowanie studentami na różnych poziomach, jak również sporo publikacji przede wszystkim w języku angielskim, ale również po szwedzku i polsku daje mi prawo do krytycznego potraktowania metody biograficznej. Artykuł ten traktuje właśnie o takim spojrzeniu krytycznym, szczególnie w sytuacji, kiedy różnorodność podejść, koncepcji i swojego rodzaju galimatiasu może sprawiać trudności w stosowaniu tej metody u nowicjuszów.

W artykule tym przedstawię początki tej metody, usytuuję ją w kontekście nauk społecznych, zastanowię się nad różnymi podejściami, pułapkami oraz zaletami i wadami tej metody. Będę się też odnosić do moich projektów badawczych, do analizy danych biograficznych, jak i budowania teorii (metodą abdukcji) wyników badań (Iddo Tavory, Stefan Timmermans 2014; Peirce 1974, 1979).

W naukach społecznych i humanistycznych widzimy różnorodność podejść do badań biograficznych - panuje w nich swoista „dżungla”. Powstaje więc pytanie, które z tych podejść jest właściwe, a które nie? Które warto stosować i dlaczego?

Za prekursora metody biograficznej w socjologii uznaje się Floriana Znanieckiego, chociaż zarówno Max Weber, jak i Charlotta Bühler (ale to psychologia) metodę tę stosowali. Znaniecki jest twórcą metody autobiograficznej, gdzie badany pisze własny pamiętnik na zadany przez badacza temat. Pamiętnikarstwo ma długą tradycję w polskiej socjologii. W USA natomiast w szkole Chicagowskiej metoda Znanieckiego rozwinęła się, prawdopodobnie dzięki Robertowi E. Parkowi, ale też antropologom, w wywiady biograficzne. W moich własnych badaniach przyjęłam opcję socjologiczną, z podstawami teoretycznymi szkoły chicagowskiej i jej głównym reprezentantem Georgiem Herbertem Meadem. A więc podejście moje wynika z symbolicznego interakcjonizmu, rozwiniętego również przez Herberta Blumera, metodologicznie zaś sięgam w pewnym stopniu do metody teorii ugruntowanej (Anselma Straussa i Barneya Glasera). Strauss był drugim pokoleniem Chicagowców, tak jak Herbert Blumer, Erving Goffman czy Norman Denzin, którzy to inspirowali moje badania, jak również pragmatyści i podejście abdukcyjne (Peirce 1974, 1979; Tavory, Timmermans 2014).

\section{Wyzwania nauk społecznych}

Nauki społeczne od dawna współzawodniczą ze sobą o przedmiot badań. Socjologia chciała odróżnić się od psychologii, która koncentrowała się na jednostce, choć obydwie nauki starają się dziś szukać związków między jednostką a społeczeń- 
stwem. Socjologia jako nauka od początku przeciwstawiała się psychologii i szukała swojej odrębności w ukierunkowaniu się na grupy społeczne i społeczeństwo. Jednak grupa społeczna bez jednostki nie istnieje, jak i jednostka bez grupy społecznej, stąd zainteresowanie socjologii zależnościami między jednostkowym i grupowym podejściem. Podczas, gdy amerykańska socjologia koncentruje się na procesach makro i mikro (np. Jeffry Alexander), w Europie przeważa rozróżnienie na jednostkę (subject) i społeczeństwo (society), albo inaczej podmiotowość (agency) i społeczeństwo (structure), np. jak u Athoniego Giddensa czy Pierra Bourdieu. To ostatnie widzimy też u Mead, gdzie „I” i „me” odpowiada właśnie za indywidualność/oryginalność jednostki i jej zakorzenienie w normach i wartościach społecznych. Według Mead self nie ma ukształtowanej struktury, lecz cały czas, jak długo jednostka żyje w społeczeństwie, rozwija się, ponieważ jest procesem społecznym.

Często mówiąc o podejściu mikro, ma się na myśli badania jakościowe, w tym badania biograficzne. Czasami nazywa się takie podejście subiektywnym w odróżnieniu od obiektywnego (badania ilościowe). Badania ilościowe bazują na próbach reprezentatywnych i poszukują wyjaśnień przez dowodzenie (justification, stosując metodę hipotetyczno-dedukcyjną), podczas gdy jakościowe szukają w różnorodności zrozumienia zjawisk i zachowań ludzkich przez odkrywanie (discovery, stosując metodę abdukcyjną i teorię ugruntowaną). Najczęściej jednak badania biograficzne mają charakter jakościowy.

Nauki społeczne, a w tym socjologia, szukają zależności i związków między jednostką a społeczeństwem, a więc zarówno chcą rozumieć (understanding), jak i wyjaśniać (explanation). Uważa się, że metoda biograficzna może pomóc w zrozumieniu tych zależności. Ale czy wszystkie badania biograficzne szukają takich związków? To zależy oczywiście od pytań badawczych, perspektywy czy tradycji, z jakich wychodzi badacz, od jego/jej ontologii i empistemologii. Czy biografie usytuowane są w życiu i przez życie (perspektywa socjologiczna), czy też opowiedziane, zawarte w przekazie słownym lub pisemnym, a więc dyskursywne? Te pierwsze nastawione są na osobę badaną (agancy) i jej historię czy karierę życiową usytuowaną w kontekście społecznym i od niego uzależnioną (socjologia, antropologia, psychologia społeczna). Te ostatnie zaś wywodzą się z nauk humanistycznych, takich jak nauki o literaturze, etnologia, historia, w których przedmiotem badania jest tekst. Ale i te mogą być skierowane na subiektywność i jednostkowość, a nie na tekst sam w sobie. Badania biograficzne mają więc zarówno socjologiczne (w tym psychologiczno-społeczne), jak i literackie korzenie. W pedagogice przeplatają się obydwa, szczególnie w analizie wywiadów biograficznych. W studiach literackich badania biograficzne koncentrują się na autorach czy pisarzach i służą do analizy tekstów literackich, biograficznych i autobiograficznych. W socjologii i pedagogice badania mają charakter empiryczny, a więc oparte są na wywiadach biograficznych ze zwykłymi ludźmi.

Jeśli chodzi o badania empiryczne, to można wymienić dwie tradycje: socjologiczną, sięgającą szkoły chicagowskiej, i antropologiczną dużo starszą. Podczas gdy 
ta pierwsza oparta była na tekstach pisanych, ta druga na przekazie ustnym. Dopiero pod koniec lat 60-tych ubiegłego wieku badania biograficzne rozkwitły ponownie jako reakcja na pozytywizm i jego krytykę, który uważano za odsunięty od rzeczywistości, oraz przez rosnące zainteresowanie ważnością jednostkowych i społecznych znaczeń/kontekstów (Prue Chamberlayne i in. 2000). Tak socjolodzy, jak i historycy zaczęli uznawać jednostkowe narracje jako skuteczny środek w rozumieniu społeczeństwa i zmian społecznych, zarówno na poziomach mikro, jak i makro.

Krytyka badań biograficznych odnosi się do ich jednostkowego charakteru i braku możliwości uogólniania, a więc reprezentatywności osób badanych. Takie stanowisko zajmowali badacze zjawisk społecznych na poziomie makro. Natomiast psycholodzy w swojej krytyce koncentrują się na sprawach pamięci, twierdząc, że narrator zapomina fakty i zdarzenia ze swego życia, a więc fabularyzuje. Francuski filozof Paul Ricœur w pracy La Mémoire, l'Histoire, l'Oubli (2000) podejmuje ciekawie problem pamięci, historii i zapominania, jak i narracji. Również historycy używają metody biograficznej w swojej oral history, gdzie interpretacja faktów z przeszłości odgrywa ważny dodatek do danych zebranych innymi metodami. Inni, jak Jeorome Bruner (1990), koncentrują się np. na opowieściach wszystkich członków rodziny, zabezpieczając się przed jednostkowym rozumieniem związków i konfliktów w grupie pierwotnej.

Ale w pogłębionych socjologicznych badaniach biograficznych nie chodzi tak bardzo o pamięć faktograficzną, ale o to, jak historia życia wpływa na nasze doświadczenia i przeżycia współczesne, czyli zastane w danej chwili, i jak kształtuje ona nasze tożsamości i postawy. W ogóle narracje biograficzne mogą tylko oddać dany stan rzeczy, a przeszłość interpretowana jest z punktu widzenia teraźniejszości. Nie podaje się więc w wątpliwość relacji osoby badanej. Badacz koncentruje się na procesie, a nie wyniku czy podsumowaniu historii życia.

\section{Metodologia}

Tak jak istnieją różne tradycje badań biograficznych, tak i są różne szkoły badań biograficznych. Tylko w socjologii można tu wymienić amerykańską szkołę chicagowską, zapoczątkowaną przez Williama Thomasa i Floriana Znanieckiego i kontynuowaną przez Clifforda Shawa (1930) w studiach nad przestępczością młodocianych. Ta rozwinęła się metodologicznie w symboliczny interakcjonizm, fenomenologię, a nawet w funkcjonalizm i strukturalizm. Rozróżniano wtedy bardziej jakościową metodę szkoły chicagowskiej i bardziej ilościową metodę szkoły Iowa. Tylko w Polsce, dzięki uczniom Znanieckiego - Józefowi Chałasińskiemu i Janowi Szczepańskiemu, przetrwała jako metoda polska obejmująca konkursy na pamiętniki. Dopiero w latach 70-tych następuje renesans metody i jej dotarcie do Europy, we Francji stosuje ją Daniel Bertaux, w Anglii Ken Plummer, Prue Chamberlayne i inni, a w Niemczech najciekawiej uczeń Straussa - Fritz Schütze. 
Zaczęto też stosować metodę biograficzną w ruchu i badaniach feministycznych (Mary Field Belenky i in. 1986), i jak pisałam wcześniej w historii i studiach nad literaturą, jak i w psychologii społecznej. Stąd mamy dziś wiele perspektyw, a badania charakteryzują się eklektycznością bądź też są bardziej ortodoksyjne.

Trudno mówić o jednej metodzie: odrębne formy, różne orientacje teoretyczne, odmienne założenia metodologiczne, procedury analizy, terminologia: biografia i autobiografia, historia życia i opowiadanie o życiu, dokumenty osobiste, różne rodzaje pogłębionych wywiadów z wywiadem narracyjnym na czele, badanie cyklów życia itd. (Włodarek, Ziółkowski 1990: 4).

Subiektywność badań biograficznych wysuwana jest jako krytyka przez badaczy ilościowych. Ale mimo że opowieść biograficzna jest skupiona na szczegółowych przeżyciach, jednostka jest również zakorzeniona w kontekście społecznym, i dlatego możemy generalizować na temat innych osób, znajdujących się w podobnej sytuacji. Również doświadczenia socjologii szkoły chicagowskiej to ilustrują. Biografie nie są więc nigdy w pełni indywidualnymi opowieściami, ujawniają także na przykład wspólne doświadczenia klasowe, płeć i pochodzenie etniczne, a więc są społeczne. Ulegają też zmianie w czasie.

\section{Metoda biograficzna}

Metoda biograficzna i wywiad biograficzny charakteryzuje się wieloma znaczeniami. Najczęściej używamy takich pojęć w socjologii i pedagogice jak auto/biografia, historii życia w socjologii, pedagogice i antropologii, narracja w psychologii, badaniach literackich i antropologii, w historii historia opowiedziana (oral history) i historia przypadku w psychologii i medycynie. Jednak istnieje różnica między narracją i historią życia. Biograficzna opowieść składa się z kilku narracji opowiedzianych w określonym czasie i przestrzeni, które razem tworzą całą opowieść życia (life story) jako część biografii danej osoby. Dlatego biograficzny wywiad trwa tak długo aż zarówno opowiadający, jak i badacz są zadowoleni z przedstawionej prezentacji, i kiedy badany wyraźnie daje znać, że całkowicie wyczerpał wątek opowiadania.

Badania biograficzne mogą wydawać się łatwe do przeprowadzenia, tak jednak nie jest. Planowanie badań wymaga przemyślenia i odpowiedzi na wiele istotnych pytań. Po pierwsze, jakie są nasze pytania badawcze, czy wychodzimy z konkretnej teorii, czy też nie. Po drugie, jakie pułapki mogą nas czekać, gdy takie badania podejmujemy. Kluczową sprawą jest relacja między wyborem podejścia teoretycznego a metodologią. Są to też pytania o indukcję czy dedukcję. Następnie, czy wywiad biograficzny będzie pogłębiony, czy lekko ustrukturyzowany? Jak 
można przeprowadzić narracyjny wywiad biograficzny, przedstawię na podstawie własnych doświadczeń, z zastosowaniem metody abdukcyjnej.

Biograficzny wywiad jest częścią badań biograficznych, które związane są z historią i doświadczeniami życia codziennego. Stosując metodę biograficzną, jesteśmy zaangażowani w pogłębiony wywiad dotyczący życia danej osoby, w interakcję między badaczem a osobą badaną, gdzie rozmówca opowiada swoją historię życia bez przerywania. Jest to proces czasochłonny, wymagający zaangażowania w narrację, opis i wyjaśniania własnego życia słuchającemu badaczowi.

Biograficzny wywiad charakteryzuje się również czasowością (temporality). Staramy się więc uchwycić zarówno dawne doświadczenia z perspektywy osoby badanej i jej obecnego rozumienia przeszłości, jak i przyszłe jej oczekiwania i możliwości. W konsekwencji historia życia danej osoby zmienia się z upływem czasu. Tak więc wywiady biograficzne tworzone są w dużej mierze przez samych badanych, co może stwarzać ogromne wymagania zarówno dla badacza, jak i rozmówcy.

Wywiad biograficzny ma dwojakie znaczenie. Daje badaczom bogaty materiał do analizy, a badanym okazję do poznania samego siebie. Kiedy dorośli opowiadają swobodnie i bez przerwania własną historię, otrzymujemy głęboką relację ich życia, postaw i wartości, a także relację o tym, jak życiowe doświadczenia wpłynęły i mogą wpływać na ich życie. Interakcja z badaczem daje czas do namysłu, a więc sięganie w przeszłość i refleksję na temat przeszłych wydarzeń, które pomagają zrozumieć własne decyzje i działania, jakie podjęliśmy w przeszłości. A więc proces opowiadania własnej historii w biograficznym wywiadzie można nazwać biograficznym uczeniem się (zob. Alheit 1995; Bron 1999, 2000).

Krytyczne zarzuty pod adresem wywiadu biograficznego dotyczą roli badacza, która może, a nie powinna przerodzić się w rolę terapeuty (do czego wrócę w dalszej części artykułu).

\section{Dostęp i dobór rozmówców biograficznych}

Angażowanie się badacza w strategie doboru osób badanych, w etyczne aspekty wywiadów biograficznych i samego przeprowadzania wywiadu wymaga głębokiego zastanowienia. Kluczowym aspektem wywiadów biograficznych jest chęć osób badanych do udziału w badaniach i chęć opowiedzenia własnej historii. Wymaga to gruntownego przygotowania naukowego, metodologicznego i etycznego.

Tak więc zaangażowanie się $\mathrm{w}$ badania biograficzne nie jest wcale łatwe, jak to się często wydaje. Niewielka teoretyczna grupa badawcza nie oznacza, że taki dobór jest prosty do osiągnięcia. W jaki sposób możemy znaleźć osoby do badań biograficznych, w jaki sposób przekonać je, aby podzieliły się swoimi historiami i wzięły udział w projekcie badawczym? Są to pytania, które badacze napotykają podczas prowadzenia wywiadów biograficznych. Strategie wyboru różnią się w zależności 
od pytań badawczych. W podejściach biograficznych jednak poszukujemy zarówno unikalnych perspektyw, jak i możliwych do porównania. Wielorakość, a nie podobieństwo jest zasadą doboru próby. Nie jest to więc dobór reprezentatywny tylko teoretyczny, w którym chodzi o znalezienie jak najwięcej przypadków wykluczających się. Jak również stosuje się zasadę nasycenia (saturation), kiedy badacz decyduje, że kolejny nowy wywiad nic nowego do analizy nie wniesie i kończy badania.

\section{Aspekty etyczne}

Względy etyczne są niezbędne przy badaniu ludzi i kilka ich aspektów należy uwzględnić przy zastosowaniu podejścia biograficznego. Przez wywiady biograficzne docieramy do ludzkich historii życia, co jest kwestią delikatną. Z jednej strony, badacz jest zaangażowany w historie życia danych osób w celu przeprowadzenia projektu badawczego; z drugiej strony, osoby opowiadające swoje historie życiowe również, czy przede wszystkim, są ich właścicielami. Dlatego ważne jest, aby zawrzeć pisemną umowę (kontrakt) opartą na wspólnej własności co do treści wywiadów i nie naruszać zaufania osoby badanej.

Umowa/kontrakt z osobą badaną zawiera: informacje na temat projektu oraz sposobu przeprowadzenia badań; prawa badanego do odmówienia odpowiedzi na niektóre pytania, do wycofania się z uczestnictwa $\mathrm{w}$ trakcie wywiadu i po jego przeprowadzeniu, a w konsekwencji pozbycie się materiału, jeśli badany tego zażąda; poufność i prawo do zachowania anonimowości poza zespołem badawczym, a wreszcie własność do wywiadu przez dostęp do transkrypcji i jego redakcji. Podpisana umowa z badanym pozwala naukowcom korzystać z materiałów, a badanemu decydować, czy pozostać anonimowym i uzyskać kopię transkrypcji, czy też nie (zob. Bron, Thunborg 2015).

\section{Jak przeprowadzać wywiad biograficzny?}

W Europejskim projekcie nad „Dostępem i retencyjnością: doświadczenia nietradycyjnych studentów w szkolnictwie wyższym" jako zespół poprosiliśmy studentów do wzięcia udziału w badaniach, wysyłając kwestionariusz do odpowiednich programów na studiach uniwersyteckich. Taka procedura wymaga czasu i odpowiedniej administracji. Wywiady zostały zaplanowane w czasie odpowiednim dla rozmówców, po wcześniejszym telefonicznym lub mailowym kontakcie. Do zaplanowania spotkania studenci potrzebowali czasu, często też zmieniali datę spotkania. Spotkaliśmy ich w kawiarniach, w ich prywatnych domach lub na uniwersytecie. Nasze pogłębione wywiady trwały od około jednej do dwóch godzin. Zaczynaliśmy od nieformalnej rozmowy i powoli rozpoczynaliśmy wywiad, zadając tylko jedno pytanie otwarte, pozwalaliśmy im opowiedzieć swoje historie do końca. 
Pytanie brzmiało: Czy mógłbyś/mogłabyś nam opowiedzieć, jak to się stało, że zacząłeś/aś swoje studia uniwersyteckie?

Dopiero po skończonej narracji badacz może przyjąć bardziej aktywną postawę i próbować skierować wywiad na pewne zdarzenia lub tematy, aby je pogłębić, i w ten sposób generować dalszą narrację osób badanych. Do niektórych studentów powracaliśmy ponownie i wtedy student zatwierdzał poprzedni wywiad, który to służył jako punkt wyjścia do kolejnego wywiadu.

Wywiad biograficzny oznacza interakcję między dwoma osobami, ale to osoba badana jest odpowiedzialna za to, co zostało powiedziane. Zadaniem badacza jest opanowanie sztuki słuchania. Krótkie przerwy ciszy przez 30 sekund lub dłużej mogą wydawać się dość długie, jednak są one ważne dla rozmówców; w przeciwnym wypadku, jeśli postawimy pytanie w trakcie, rytm i struktura narracji zostaje przerwana. Balansowanie badacza między bliskościq a dystansem w relacji do osoby badanej jest konieczne i osiągane stopniowo wraz z doświadczeniem. Badacz musi wczuć się w rolę osoby badanej przez rozumienie jej punktów odniesienia (frame of reference), używając wspólnego języka, będąc empatycznym, reagując na gesty i postawy, będąc cierpliwym i asertywnym. Jednakże, badacz musi również mieć świadomość, aby nie popaść w spoufalenie (go native), co by oznaczało utratę krytycznej i refleksyjnej postawy, i stanie się zbyt sympatycznym. Wymaga to kształcenia i samorefleksji.

\section{Analiza danych biograficznych - różne podejścia}

Analiza danych $\mathrm{z}$ wywiadów biograficznych jest kluczowa w procesie badawczym nie tylko, aby odpowiedzieć na postawione pytania badawcze, ale również dla szukania koncepcji i związków miedzy nimi i teoretycznego wyjaśniania procesów, które badaliśmy. W zależności od tego, jak dużym materiałem dysponujemy, możemy stosować różne metody analizy danych. Wszystkie te metody mają to do siebie, że polegają na zastosowaniu metody porównawczej. W moich własnych badaniach inspirowała mnie metoda teorii ugruntowanej Glasera i Straussa, którą rozwinęła m.in. Kathy Charmaz. Istnieją dziś różne metody komputerowe analizy danych, ale w mojej grupie badawczej preferujemy metodę pogłębioną „ręczną”, polegającą na czytaniu i interpretacji, słowa po słowie, zdania po zdaniu w zespole trzech osób. Do analizy potrzebna jest też umiejętność konceptualizacji, o której pisze Glaser (2002).

Po zebraniu wywiadów zaczęliśmy transkrypcję, słowo po słowie, ale nie zdanie po zdaniu. Przekaz mówiony nie ma przerw, składa się z przepływu słów, więc nie wiemy, kiedy zdanie się zaczyna, a kiedy kończy. Transkrypcja zabiera czas, aby przepisać godzinny wywiad, potrzeba ok. 8 godzin i daje, w zależności od tego, jak szybko rozmówca mówi, ok. 12 pisemnych stron. To jest oczywiście jedna z wad badań biograficznych i wtedy kiedy wywiadów mamy wiele, ich przepisywanie 
pochłania bardzo dużo czasu. Mimo to jesteśmy zwolennikami pełnej transkrypcji wywiadów w oryginalnych wersjach, ponieważ transkrypcja jest pierwszym momentem analizy. Zaczynamy od tego/tych wywiadów, które pamiętamy jako najbardziej godne uwagi. Jednak nie musimy dokonać transkrypcji wszystkich wywiadów naraz, zanim rozpoczniemy analizę.

\section{Sześć etapów/faz analizy danych biograficznych}

Sposób analizowania danych biograficznych naszego zespołu (Bron, Edström, Thunborg) był inspirowany przez teorię ugruntowaną Glasera i Straussa i składał się z sześciu etapów, jeśli chodzi o analizę kodowania otwartego (open coding).

1. Używanie pojęć syntetyzujących (sensitising concepts) z literatury naukowej lub danych empirycznych (in vivo). Pierwszy etap składał się z definiowania pojęć teoretycznych jako syntetyzujących koncepcji dla zrozumienia procesów tworzenia i przekształcania tożsamości studentów. Początkowo nasza perspektywa teoretyczna zwrócona była w kierunku koncepcji Meada na temat kształtowania osobowości (self) i z odniesieniem do opracowanej przez Giddensa koncepcji agency (podmiotu działajq̨cego) i struktury. Faza ta może być oczywiście oparta również na danych empirycznych, ale w naszym wypadku tak rozpoczęliśmy proces analizy.

2. Zbiorowy proces otwartego kodowania. Z syntetyzującym pojęciem $\mathrm{w}$ pamięci zaczęliśmy analizę danych, czytając transkrypcje w grupie trzech badaczy. Czytaliśmy słowo po słowie, zdanie po zdaniu, aż do uzyskania jasnego zrozumienia doświadczeń studentów. Zaangażowani byliśmy w intensywną dyskusję i kwestionowanie założeń traktowanych jako pewniki. Po pierwszym wyborze jednego biograficznego wywiadu, zwróciliśmy szczególną uwagę na kwestię tworzenia tożsamości, reprezentując, jako badacze, różne doświadczenia i własne historie życiowe, co pomogło nam w interpretacji i uzyskaniu wielorakiego rozumienia konkretnej osoby.

3. Formułowanie winiet $i$ analizowanie doświadczeń. Winieta jest streszczeniem historii jednego człowieka, w którym wszystkie ważne wydarzenia i doświadczenia z życia danej osoby są brane pod uwagę. Streszczenie jest opisowym sposobem analizowania danych, co umożliwia badaczom usystematyzowanie materiału, ponieważ każdy przypadek jest skrócony do minimum. Jednak bogatsza relacja przyczynia się do dłuższego tekstu. Porównywanie i zestawianie winiet jest sposobem analizowania doświadczeń studentów/badanych.

4. Tworzenie rozumienia teoretycznego i rozwijanie nowych pojęć. Po gruntownej analizie jednego studenta zwróciliśmy się ponownie do koncepcji: tożsamości, agency i struktury. Umożliwiło nam to zdefiniowanie trzech typów tożsamości uczenia się, mianowicie: niepowodzenie w uczeniu (the learning failure), instrumentalne uczenie się (the instrumental learner) i dobrego uczącego się (the good learner). Analiza była synchroniczna, gdzie każda tożsamość została skonstruowana 
w odniesieniu do znaczącego okresu życia studenta. Koncepcja struktury i agency Giddensa pomogła nam tu zrozumieć, jak każdy okres został organizowany.

5. Szukanie nowych pojęć syntetyzujacych, zawieszenie (floating) dla zrozumienia zmian $w$ tożsamości. Koncepcja zawieszenia (Bron 2000) okazała się przydatna dla jeszcze głębszego zrozumienia oraz pozwoliła zastanowić się szczególnie nad doświadczeniem kryzysu uczenia się u studenta.

6. Podjęcie dalszej analizy. Ostatni etap obejmował analizę diachroniczną, czyli próbę zbadania okresów zmian w miarę upływu czasu. Stosując pojęcie zawieszenia (floating), mogliśmy zidentyfikować, kiedy rozpoczął się kryzys w uczeniu się u studenta i kiedy wycofał się ze studiów.

Z naszego doświadczenia wynika, że otwarte kodowanie trwa bardzo długo i że rola analityków jest tu wiodąca. Jedną z koncepcji zidentyfikowanych w historiach życia studentów, które doprowadziły nas dalej w naszych analizach, była koncepcja zmagań (struggles). Ich zmagania pomogły nam zrozumieć zarówno zależność między strukturą i agency, jak i tworzenie tożsamości oraz procesów transformacyjnych w ciągu życia człowieka.

\section{Kodowanie selektywne danych biograficznych}

Kiedy analizowaliśmy wielokrotnie zebrany materiał biograficzny, staraliśmy się dokonywać porównań, szukając podobieństw i różnic w celu maksymalizacji i minimalizacji danych, czyli używając wąskiej i szerokiej perspektywy. Szukaliśmy procesów w opowieściach życia i pomiędzy nimi, aby znaleźć takie narracje, które pasowały bądź nie pasowały do siebie. Opracowywaliśmy winiety poszczególnych biografii studentów po wnikliwej analizie, którą braliśmy pod uwagę. Szukaliśmy wątku przewodniego, motywu lub kategorii podstawowej, w porównaniu z innymi wywiadami (winietami). Testowaliśmy naszą pojawiającą się hipotezę i kategorie na wciąż nowych materiałach biograficznych. Nasze koncepcje pojawiały się, gdy okrywaliśmy procesy w dynamicznych danych biograficznych. Kiedy studenci opowiadali nam swoje historie, przeżycia i odczucia, jakie podejmowali działania, i co podkreślali jako ważne dla nich, byliśmy w stanie uchwycić podstawy w ich podejściu. Odkrywaliśmy sekwencje życia i czasowość danych (opowieści opowiedziane, refleksje i wyjaśnienia w kategoriach uzasadniania swoich postępowań). Co więcej, wszystkie kroki przyczyniły się do „otwierania” danych, a ostatecznie skupiliśmy się na tym, co się z nich wyłoniło, stawiając pytania skierowane do materiałów biograficznych i do siebie samych.

Rezultatem naszej analizy nie było szukanie odpowiedzi na hipotezy wcześniej przyjęte, ale szukanie i testowanie wciąż nowych hipotez, teoretyzowanie i uogólnianie odniesione jedynie do danej badanej grupy.

Przejdę teraz do przykładu wynikającego $\mathrm{z}$ analizy wyników naszych badań, posługując się metodą teorii ugruntowanej. 


\section{Przykład z własnych badań}

W Europejskim projekcie nad „Dostępem i retencyjnością: doświadczenia nietradycyjnych studentów w szkolnictwie wyższym” (RANLHE Project, Access and Retention: Experiences of Non-traditional Learners in HE, 2011-2014) zastosowaliśmy metodę biograficzną i przeprowadziliśmy w Szwecji 100 pogłębionych wywiadów narracyjnych ze studentami na początku i końcu procesu ich studiów, jak i też kilkakrotnie w procesie trzyletnich studiów (badanie podłużne). Badania te posłużą za przykład krytycznego podejścia do metody biograficznej (Bron 2009; Bron, Thunborg 2015, 2016; Thunborg, Bron, Edström 2011, 2012, 2013; Bron, Edström, Thunborg 2010, 2012; Bron, Thunborg, Edström 2013, 2014).

Dlaczego używamy metody biograficznej w naszych badaniach nad studentami nietradycyjnymi? Chodzi nam głównie o zrozumienie zmagań studentów z ich tożsamościami na studiach, zarówno kiedy zaangażowani są w procesy tworzenia, jak i przekształcania swych tożsamości, biorąc pod uwagę ich społeczne pochodzenie, osobiste doświadczenia w konkretnym czasie i jako trwający proces biograficzny.

\section{Typologia studentów nietradycyjnych}

Pytania nasze dotyczące tożsamości studentów - jej kształtowanie i przekształcanie, po gruntownej analizie transkrypcji wywiadów biograficznych (kiedy grupa badaczy zmagała się ze zrozumieniem opowieści życiowych studentów), zaowocowały typologią studentów nietradycyjnych. Rysunek 1 przedstawia typologię

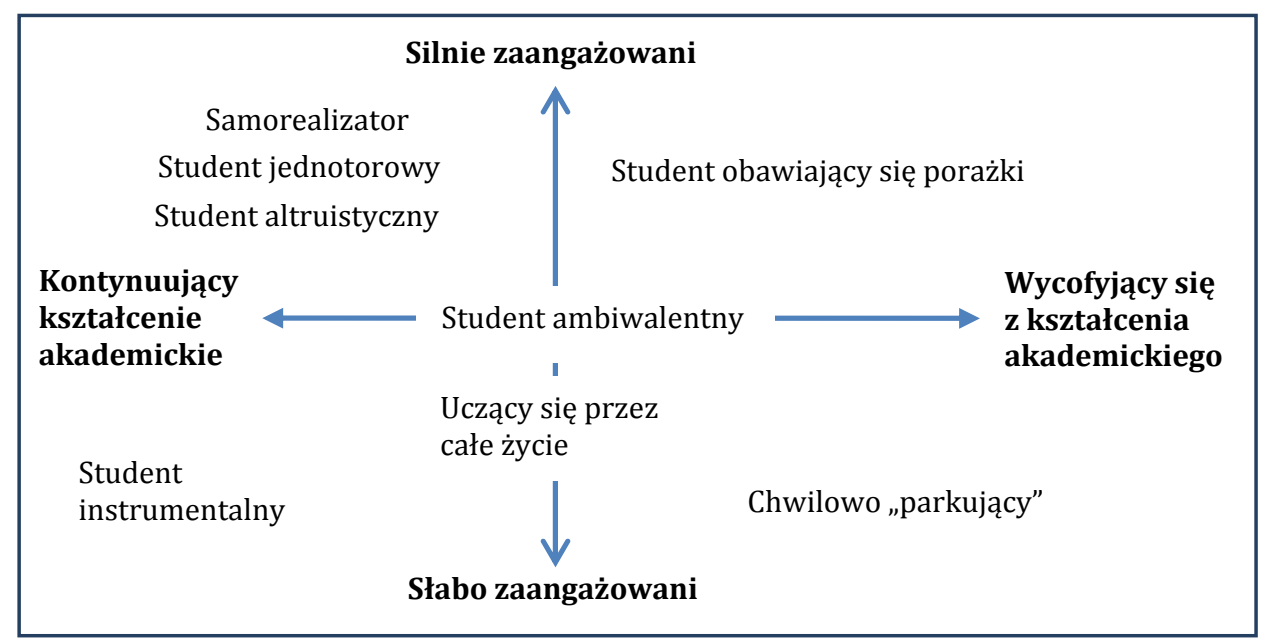

Płynna tożsamość studentów

Rys. 1. Typologia tożsamości nietradycyjnych studentów w Szwecji

(C. Thunborg, A. Bron, E. Edström (2013), s. 190) 
studentów szwedzkich badanych w latach 2011-2014. Nazwaliśmy ją płynną tożsamością, ponieważ żaden z tych typów nie do końca charakteryzuje studenta, jest tylko prowizoryczny, zmieniający się w zależności od sytuacji społecznej, w której studenci się znajdują.

Studentów nietradycyjnych określiliśmy jako pierwszych w swojej rodzinie wybierających się na studia, choć też i inne cechy brane były pod uwagę, tj. płeć, wiek, rodzaj studiów (dla pracujących), jak również pochodzenie etniczne.

Analiza biografii studentów przedstawiona jest na dwóch osiach, które tworzą cztery pola - oś wertykalna: od silnie zaangażowanych w swoje studia uniwersyteckie do słabo zaangażowanych, i oś horyzontalna: od kontynuujących studia do wycofujących się $\mathrm{z}$ uczestnictwa $\mathrm{w}$ szkolnictwie wyższym lub też wybranym kierunku studiów. Analizując pogłębione wywiady ze studentami, które były ukierunkowane zarówno na ich kariery uczenia się oraz na kształtowanie tożsamości, jak i jej przekształcanie, wyróżniliśmy typowe tożsamości, które umiejscowiliśmy $\mathrm{w}$ czterech polach przedstawionych na powyższym rysunku. Te wyłonione tożsamości to:

- „Altruistyczny student”, który chce używać wiedzę zdobytą na studiach, pomagać innym lub aby przyczynić się do zmian społecznych. Jest silnie utożsamiony z uczelnią;

- „Student ambiwalentny” rozpoczynający studia na poziomie wyższym tylko czasowo, na próbę, borykający się z przynależnością/identyfikacją do/z uczelni(ą), stopniowo okazując zainteresowanie szkolnictwem wyższym (SzW). Student taki nie jest ani silnie, ani słabo zaangażowany w SzW.

- „Student zaparkowany” studiuje, aby coś robić, czekając na zatrudnienie i w związku z tym jest słabo zaangażowany w SzW, wycofuje się, kiedy traci zainteresowanie i ponownie zaczyna/powraca, kiedy nic innego bardziej ciekawego się nie dzieje.

- „Student instrumentalny” studiuje, aby osiągnąć zatrudnienie, lepsze życie albo status społeczny, ale nie wydaje się, aby był zainteresowany zdobyciem wiedzy; jest więc słabo zaangażowany w SzW, „używa” studiów bardziej dla własnej ruchliwości społecznej niż chęci osiągnięcia wiedzy (posiadanie dyplomu jest więc jego jedynym celem).

- „Student całożyciowego uczenia się” jest zainteresowany i uczy się, ale nie ma ochoty na zdawanie egzaminów (nie jest mu to potrzebne). SzW traktuje jako przestrzeń, jak inne miejsca w życiu, dla uczenia się, rozpoczęcia nowego kursu lub wycofania się w zależności od zainteresowania w danej chwili. Najczęściej jest to student pracujący albo na emeryturze.

- „Student jednotorowy” jest zainteresowany jedną dziedziną, z silnym zaangażowaniem w uczelnię, którą postrzega jako arenę wiedzy.

- „Student obawiający się porażki” ryzykuje wycofaniem się ze SzW, będąc silnie zaangażowanym, ma jednak kłopoty ze zdawaniem egzaminów i czynienia 
zadość innym, których oczekiwania i wymagania w stosunku do niego są wysokie. Definiując siebie jako nieudacznika, nie ma możliwości pozostania w SzW.

- „Samorealizator” najczęściej jest starszym/dorosłym studentem, który po gruntownej zmianie życiowej rozpoczyna studia. SzW staje się sceną jego osobistego rozwoju, jest silnie zaangażowany w SzW, podejmujący osobiste poświęcenia, aby móc studiować lub okazuje chęć takiego działania.

\section{Krytycznie o typologii}

Oczywiście można na taką typologię spojrzeć krytycznie z punktu widzenia dwóch aspektów. Pierwszy, to problemy z uogólnieniem, a więc reprezentatywnością materiału badawczego. Drugi, to bardziej problem etyczny z „szufladkowaniem” studentów. Do czego taka typologia służy? Czy nie jest to czasem przyklejaniem etykietek? Chodzi tu jednak o uogólnienia nie na poziomie jednostkowym, ale społecznym.

Max Weber używał określenia: typy idealne, jak i Znaniecki z Thomasem (1976), którzy opracowali typologię polskich chłopów emigrantów. Fakty społeczne traktował Znaniecki, podobnie jak Durkheim, jako: „jedynie naukowe badanie, które jest całkiem wolne od praktyki może stać się użyteczne w praktycznym zastosowaniu" (Thomas, Znaniecki 1976, 1: 45).

Thomas i Znaniecki $(1918,1920)$ chyba jako pierwsi zajęli się uogólnianiem danych z materiałów i dokumentów biograficznych, wyodrębniając nieliczne i określone typy osobowości (self), przyczyniając się do rozwoju psychologii społecznej, socjologii rodziny i zmian życiowych spowodowanych emigracją. Mimo że mieli do czynienia z wieloma biografiami, liczba ich możliwych wariantów była ograniczona, można więc było zredukować je do trzech zasadniczych typów: filistrów, cyganów i jednostek twórczych (zob. Thomas, Znaniecki 1976, 3: 20-22). Typy te są bardziej lub mniej zorganizowane, w pierwszym wypadku dominuje pragnienie bezpieczeństwa, w drugim nowego doświadczenia, a w trzecim zachowanie równowagi między dążeniem do nowości a osiągnięciem minimum stabilizacji. „Te trzy ogólne typy - kierunki rozwoju osobowości - zawierają rzecz jasna, nieograniczoną ilość odmian zależnych od postaw kształtujących charakter i od schematów organizacji życia ludzkiego w społeczeństwie" (tamże: 22).

Nasza typologia tożsamości studentów traktuje ich tożsamości jak proces tworzenia i przekształcania nigdy tak naprawdę niezakończony, a więc w zgodzie zarówno z Meadem, jak i Znanieckim, w zakresie traktowania osobowości. Można takie stanowisko podważać, jeśli traktuje się osobowość jako strukturę, a nie proces. Ma to oczywiście uzasadnienie w podejściu ontologicznym.

Pułapką badań biograficznych jest urojona łatwość ich przeprowadzenia. Tymczasem wymagają one gruntownego przygotowania w dotarciu i doborze osób 
badanych, przeprowadzeniu wywiadu biograficznego, transkrypcji, a następnie analizy.

Również rola badacza jest ważna, trzeba ją opanować, balansując między bliskością a dystansem, subiektywnością a obiektywnością, jednostkowością a społecznością. Badacz biograficzny charakteryzuje się więc integracją, etyką, rzetelnością, umiejętnością i wiedzą z zakresu nauk społecznych.

\section{Praktyczne wnioski dotyczące stosowania metody biograficznej}

Czego możemy się nauczyć, aby jak najlepiej zastosować metodę biograficzną. Oto kilka rad:

- Po pierwsze, bądź wrażliwym w stosunku do osoby badanej. Jako że biograficzne podejście oparte jest na historii życia osób badanych, ważne jest, aby stosunek do rozmówcy był traktowany z ostrożnością i umiejętnie. Spróbuj umówić się z wyprzedzeniem czasowym i oprzeć spotkanie na wzajemnym zainteresowaniu w przeprowadzeniu wywiadu, uważnie słuchaj opowieści podczas wywiadu i staraj się nie przerywać osobie opowiadającej własną historię.

- Po drugie, dokonaj transkrypcji i analizy wywiadów tak dokładnie, jak to możliwe. Bądź świadomy swoich pytań badawczych podczas całego procesu kodowania, ale także różnorodności w opowieści. Jeśli to możliwe, to w początkowym kodowaniu historii życia koduj w grupie. Poszukiwanie pojęć, tworzenie szkiców, rysunków, jak i pisanie winiet jest pomocne w analizie danych biograficznych. Proces ten, jak również testowanie koncepcji i pojęć na nowych wywiadach, aby móc generalizować, jest twórczy i prowokujący, ale też przynosi satysfakcję.

- Po trzecie, zaletą korzystania z biograficznego podejścia jest to, że przynosi bogatą i owocną wiedzę o ludziach, sytuacjach życiowych i sobie samym, a także jest dość ekskluzywną działalnością dla badaczy. Jeśli nie masz ochoty, aby dowiedzieć się o skomplikowanych doświadczeniach życiowych innych ludzi, należy wybrać inne podejście.

\section{Problemy i trudności w prowadzeniu badań biograficznych}

Praca badawcza z wykorzystaniem wywiadu biograficznego jest rzeczywiście ciekawym sposobem prowadzenia badań i wobec tego może mieć wielu zwolenników. Jednakże istnieją problemy i trudności, z którymi borykają się nowicjusze, ale też wytrawni badacze, stosując biograficzne podejście:

1. Badania wymagają czasu i cierpliwości, a także wyobraźni i twórczości.

2. Potrzebne jest dobre przygotowanie teoretyczne i metodologiczne, ale również doświadczenie praktyczne.

3. Wymagana jest etyczna rozwaga przy wyborze konkretnych osób do badań, jak również w samym prowadzeniu badań i raporcie z wyników. 
4. Mamy do czynienia ze złożonym procesem jakościowej analizy, jako że opowieść obejmuje szereg różnych narracji, które trzeba wziąć pod uwagę i analizować.

Pogłębione badania biograficzne dostarczają wielu możliwości, ale nie są wcale łatwe do przeprowadzenia, jak pokazuje ten artykuł. Niemniej jednak są odkrywcze i mogą prowadzić do teoretyzowania badanych zjawisk społecznych. Wymagają też gruntownego przygotowania teoretycznego, metodologicznego i etycznego.

\section{Bibliografia}

Alexander J., Thompson K. (2008) A Contemporary Introduction to Sociology: Culture and Society in Transition, Boulder, Colorado, Paradigm Publishers.

Alheit P. (1995) Biographical learning. Theoretical outline, challenges and contradictions of a new approach in adult education w: The Biographical approach in European adult education, P. Alheit et al. (ed.), Wien, Verband Wiener Volksbildung/ESREA, s. 57-74.

Belenky M. F., Clinchy B. M., Goldberger N. R., Tarule J. M. (1986) Women's Ways of Knowing, New York, Basic Books.

Bertaux D. (ed.) (1981) Biography and Society, Beverly Hills, University of California.

Blumer H. (1954) What is Wrong with Social Theory?, "American Sociological Review", no 19 , s. 3-10.

Bourdieu P. (1990) The Logic of Practice, Cambridge, Polity Press.

Bron A. (1999) The Price of Immigration. Life Stories of Two Poles in Sweden, "International Journal of Contemporary Sociology", no 36/2, s. 191-203.

Bron A. (2000) Floating as an analytical category in the narratives of Polish immigrants to Sweden w: Allvarlig debatt and rolig lek, En festskrift tillägnad Andrzej Nils Uggla, Uppsala. Uppsala, Universitet, Centrum för multietnisk forskning, s. 119-132.

Bron A. (2007) Learning, Language and Transition w: Using biographical and life history approaches in the study of adult and lifelong learning: perspectives from across Europe, L. West et al. (eds.), Frankfurt, Peter Lang, s. 205-220.

Bron A. (2009) Biograficzność w badaniach biograficznych, „Dyskursy Młodych Andragogów", nr 10, Zielona Góra, Uniwersytet Zielonogórski, s. 37-54. 
Bron A., Edström E., Thunborg C. (2010) Struggles in Student Identity - A Space for Poetry, ESREA Life History and Biography Network Conference, Växjö University College.

Bron A., Edström E., Thunborg C. (2012) 'To Make a Difference for the Others and Myself': Second Generation Immigrants Students' Learning Narratives in Sweden, ESREA Migration, Racism, and Xenophobia Research Network Conference, Karl-Franzens Universität Graz.

Bron A., Schemmann M., (eds.) (2002) Social Science Theories and Adult Education Research, BSIEA, vol. 3, Münster, Lit Verlag.

Bron A., Thunborg C. (2015) Biographical interviewing. The case of non-traditional students in higher education. SAGE Research Methods Cases, http://srmo.sagepub. com/page/help-1/help

Bron A., Thunborg C. (2016) O teoretyzowaniu danych biograficznych. Przypadek studentów nietradycyjnych, „Teraźniejszość - Człowiek - Edukacja. Kwartalnik myśli społeczno-pedagogicznej", nr 3 (75), vol. 19, s. 139-153.

Bron A., Thunborg C., Edström E. (2013) Theorizing Learning Lives of Non-Traditional Students. Paper presented at the ESREA Life history and Biographical Research Network, Canterbury 28 February - 3 March 2013.

Bron A., Thunborg C., Edström E. (2014) Ethnicity and Class, Does it Matter? w: Student voices on inequalities in European Higher Education, F. Finnegan, B. Merrill, C. Thunborg (eds.), London, Routledge, s. 63-73.

Bron-Wojciechowska A. (1989) Workers and Post-Secondary Education. A Cross Polity Perspective, Uppsala, Uppsala Studies in Education 31, Acta Universitatis Upsaliensis.

Bruner J. (1990) Acts of Meaning, Harvard, Harvard University Press.

Chamberlayne P., Borna J., Wengraf T. (eds.) (2000) The Turn to Biographical Methods in Social Science Comparative issues and examples, New York, Routledge.

Denzin N. (1989) The Research Act: A Theoretical Introduction to Sociological Methods, New Brunswick, Transaction.

Dulczewski Z. (1984) Florian Znaniecki życie i dzieło, Poznań, Wydawnictwo Poznańskie.

Durkheima É. (1895) Les règles de la méthode sociologiqu. The Rules of Sociological Method, Paris, Librairie Félix Alcan. 
Giddens A. (1991) Modernity and Self-Identity, Self and Society in the Late Modern Age, Cambridge, Polity Press.

Glaser B. (1992) Basics of Grounded Theory Analysis, Mill Valley, Sociology Press.

Glaser B. (2002) Conceptualisation. On Theory and Theorising Using Grounded Theory w: Social Science Theories and Adult Education Research, A. Bron, M. Schemmann (eds.), BSIEA, vol. 3, Münster, Lit Verlag, s. 313-335.

Glaser B., Strauss A. (1967) The discovery of grounded theory, Chicago, Aldine.

Mead G. H. (1934) Mind, Self and Society. A Standpoint from a Social Behaviorist, Chicago, University of Chicago Press.

Peirce Charles S. (1974, 1979) Collected Papers, Published by Charles Hartshorne, Paul Weiss and Arthur Burks. Cambridge (Mass.), The Belknap Press of Harvard University Press.

Ricœur P. (2000) La Mémoire, l'Histoire, l'Oubli, Paris, Èditions du Seuil.

Riemann G., Schütze F. (1992). 'Trajectory' as a main theoretical concept in analysis of social processes of suffering and disorder, „Kultura i Społeczeństwo”, no 2.

Schütze F. (1987) Das narrative Interview in Interaktionsfeldstudien w: Studiebrief der Fernuniversität, Hagen, FB Erzichungs- und Sozialwissenschaften.

Shaw C. (1930) The Jack-Roller. A Delinquent Boy's Own Story, Chicago, The University of Chicago Press.

Strauss A. (1987) Qualitative Analysis for Social Scientists, Cambridge, Cambridge University Press.

Szacki J. (1986) Znaniecki, Warszawa, Wiedza Powszechna.

Szewczuk W. (1959) Psychologia człowieka dorosłego. Wybrane zagadnienia, Warszawa, Wiedza Powszechna.

Tavory I., Timmermans S. (2014) Abductive analysis. Theorizing Qualitative Research, Chicago, The University of Chicago Press.

Thomas I. W., Znaniecki F. (1918-1921) The Polish Peasant in Europe and America, Boston, Mass., Badger.

Thomas I. W., Znaniecki F. (1976) Chłop polski w Europie i w Ameryce, t. 1-5, Warszawa, Ludowa Spółdzielnia Wydawnicza. 
Thunborg C., Bron A., Edström E. (2011) Forming and transforming learning identities in higher education w: Raamat Öppimisest (The book of learning), L. Jögi, K. Krabi (eds.), Tallinn, Tallinn Ûlikooli Kasvatusteaduste Instituut.

Thunborg C., Bron A., Edström E. (2012) Forming learning identities in higher education in Sweden, "Studies for the Learning Society", no 2-3, s. 23-34.

Thunborg C., Bron A., Edström E. (2013) Motives, commitment and student identity in higher education - Experiences of non-traditional students in Sweden, "Studies in Education of Adults", no 45 (2), s. 177-193.

Włodarek J., Ziółkowski M. (1990) (red.) Metoda biograficzna w socjologii, Poznań, PWN. 